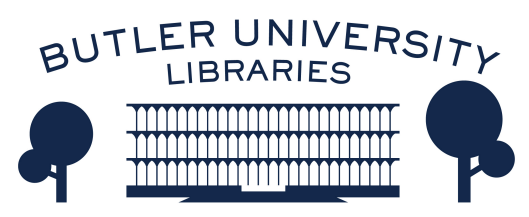

Journal of Hindu-Christian Studies

Volume 4

Article 4

January 1991

\title{
Translating, Teaching, Conversing: A Reflection in Response to the Essays of Richard DeSmet and John Carman
}

Francis X. Clooney

Follow this and additional works at: https://digitalcommons.butler.edu/jhcs

Part of the Religion Commons

\section{Recommended Citation}

Clooney, Francis X. (1991) "Translating, Teaching, Conversing: A Reflection in Response to the Essays of Richard DeSmet and John Carman," Journal of Hindu-Christian Studies: Vol. 4, Article 4.

Available at: https://doi.org/10.7825/2164-6279.1042

The Journal of Hindu-Christian Studies is a publication of the Society for Hindu-Christian Studies. The digital version is made available by Digital Commons @ Butler University. For questions about the Journal or the Society, please contact cbauman@butler.edu. For more information about Digital Commons @ Butler University, please contact digitalscholarship@butler.edu. 


\title{
Translating, Teaching, Conversing:
}

\section{A Reflection in Response to the Essays of Richard DeSmet and John Carman}

\author{
Francis X. Clooney, S.J. \\ Boston College
}

\begin{abstract}
AFTER READING "R. de Nobili as Forerunner of Hindu-Christian Dialogue" by Richard DeSmet, S.J., and "A Forgotten Dialogue: Protestant Bible Translations" by John B. Carman, one immediately recognizes the truth of Carman's insight that the Protestant Bible translators were engaged in a real encounter with Indian thought, even a true (though poorly documented and perhaps unintended) dialogue. Though their language skills were often minimal, and their interest in India's religions even less developed, their commitment to the project of translating the Bible provided numerous occasions for the missionaries and their pandits to search together for correct renderings of Biblical terms, and thereby to engage inevitably in more complex efforts to understand properly across linguistic and cultural boundaries. It is indeed unfortunate that we know so little about those pandits and their precise contribution to the translations which appeared.

One can hardly avoid noticing too, as Carman suggests, that the translators' dialogue was in important ways different than that pursued by Roberto de Nobili, S.J. He learned the languages himself, and did so before any intensive efforts to speak to the learned men of Madurai; he grew familiar with the texts he had access to (though we wish we knew more about what he actually did read, since his extant Tamil works rarely cite Hindu texts,) before he taught his way of proper thinking. As DeSmet shows us, de Nobili was a master pedagogue who rendered his audience docile and attentive before gently leading the best students among
\end{abstract}

them toward the truth he possessed. Perhaps too, this pattern of teaching was well established long before he began to compose his massive presentations of the Christian faith in Tamil, works with strong apologetic overtones.

If we thus recognize with Carman that both de Nobili and the translators offer us models for dialogue, a "teaching model" and a "translation model," our understanding of the dynamics of dialogue will have been greatly advanced. Each model has its own benefits, challenges and problems, and there is no a priori reason for all to choose one over the other.

One might also wonder, though, about how deep the difference between the two models goes. The difference might simply be traced back, for instance, to the fact that the translators were mostly Protestant and de Nobili a Roman Catholic. From this angle it is no surprise that whereas they began with a rendering of the Word of God into the local language, confident that God has endowed humans with the capacity to receive this Word once it is available to them, de Nobili never translated the Bible, or any part of it, into Tamil or Sanskrit or Telegu. (Though he may have translated a life of Christ into Tamil, and perhaps even composed [part of] one in Sanskrit.) Instead, since de Nobili had enormous respect for and loyalty to his Church's systematization of the Catholic Faith, its long-standing determination of the Bible's meaning, his immediate goal was to translate that Catholic system, and not the Bible, into the local language, trusting that evangelization could begin with the acquisition of right thinking. 
22 Francis X. Clooney, S.J.

That he gained linguistic and cultural proficiency first is admirable and distinctive, but does not constitute evidence that his intention differed from that of the translators. Both de Nobili and the Protestant translators, by legitimately and interestingly different paths, were acquiring the languages they needed to bring Hindus to salvation. For the Protestants, it was the language of the Bible, for de Nobili, the language of the Church's systematic theology. Both were quite willing to learn from local sources-pandits, books-whatever they needed to know.

This leads me to reassert my opinion, correctly noted by DeSmet, that there remains a major divide between us and de Nobili, a divide which remains significant even if one may legitimately prefer not to measure it by the scale of pre-modern, modern, and post-modern, and even if one legitimately insists that there is much we still have (or wish to have) in common with de Nobili. The divide is not about sympathy or courtesy, or pedagogical skills, or the extent of one's commitment to dialogue as a way of life. Observation of the modern world does not readily support the view that all the virtues of understanding would be on "our" side of the divide, and I am willing to defer to de Nobili regarding all these virtues. The issue is rather whether or not one has, or thinks one has, a complete rationale for one's faith, completely worked out and in need only of translation, before one even meets a person from another religion. My guess is that fewer of us today have any such rationale firmly in place, and that many are learning to live without a perfected rationale, progressing instead by means of a series of incomplete and practical rationales which remain ever open to revision in light of new situations.

By contrast, nothing about de Nobili's admirable learning and inviting openness leads to the conclusion that he thought of himself as doing anything more than translating his Catholic faith by finding appropriate terms in the local context. Though he learned many important things in India about culture and human nature and values, I do not think that he would admit that he was learning anything about God or the supernatural realm, or was acquiring a more appropriate language about these. Indeed, from a contemporary standpoint one could argue that the Protestant "translation model" of dialogue might today actually be more open and more fertile than de Nobili's, since the Bible is a far less homogenized text than the Catholic system de Nobili intended to communicate. His creativity was dedicated to preparing the way for a system of thought, while the translators were bestowing the unpredictable entirety of the Bible on the new cultures.

Or one might hearken back to the view of Jacques Dupuis, S.J., which (as Carman observes) DeSmet cites with some disapproval: "Interreligious dialogue constitutes a mutual evangelization under the impulse of the Spirit." A thorough inquiry into the prerequisites and implications of "mutual evangelization" remains undone, and one may yet conclude that "mutual" and "evangelization" do not belong together. Nevertheless, Dupuis' phrase pushes us to the front edge of dialogue's explorations today, and avoids resting dialogue on language codified in a single text, such as the Bible, or on a single refined discourse, such as de Nobili's Catholic system. Instead, this "mutual evangelization" may rest on the dynamics of language as event, an ongoing communication in which words, starting points and intended goals are necessary and instruments of divine grace, but always and without exception open to revision. Is this a third model of dialogue, a "conversation model"?

Were this to emerge as a viable model (we could ask Dupuis about this,) it would confront us with another consequence, that it would no longer be possible for us Christians to decide among ourselves what dialogue is, or how it is to be done. We would no longer be able to fine-tune our model(s) and then try it (them) out on willing non-Christians, but would have to converse with these people of other faiths about the whole problem, from the beginning. 